\title{
Assessment of antioxidant, anticancer and antimicrobial activity of two vegetable species of Amaranthus in Bangladesh
}

M. Abdulla Al-Mamun, Jamiatul Husna, Masuda Khatun, Rubait Hasan, M. Kamruzzaman, K. M. F. Hoque, M. Abu Reza and Z. Ferdousi*

\begin{abstract}
Background: Amaranthus (Amaranthaceae) has previously been reported to possess different bioactive phytochemicals including phenols, tannins and flavonoids. The current study was designed to evaluate the antioxidant, anti-proliferative and antimicrobial activity of stem and seed extracts of Amaranthus lividus (AL) and Amaranthus hybridus (AH), respectively.

Methods: Antioxidant activity of methanol extract was assessed by DPPH radical scavenging assay. Determination of lectin activity of Amaranthus extract was carried out using hemagglutination assay on mouse blood. A total of thirty six Swiss albino mice containing Ehrlich's ascites carcinoma (EAC) cells were treated with AL and AH extract at 25, 50 and $100 \mu \mathrm{g} / \mathrm{ml} /$ day/mouse for six days. Growth inhibitory activity was determined by haemocytometer counting of EAC cells using trypan blue dye and DAPI (4,6-diamidino-2-phenylindole) staining was used to assess apoptotic cells. Gene amplification study was conducted to observe the expression pattern of p53, Bax, Bcl-2 and caspase-3 mRNA using PCR (polymer chain reaction) technique. In vitro susceptibility of five pathogenic bacteria including Escherichia coli, Pseudomonas aeruginosa, Bacillus subtilis, Salmonella typhi and Staphylococcus aureus was detected using disk diffusion assay.
\end{abstract}

Results: The radical scavenging assay indicated that $\mathrm{AH}$ and $\mathrm{AL}$ possesses potent antioxidant potential, exhibiting $I_{50}$ value of $28 \pm 1.5$ and $93 \pm 3.23 \mu \mathrm{g} / \mathrm{ml}$, respectively. Hemagg lutination assay revealed that $\mathrm{AH}$ and $\mathrm{AL}$ agg lutinated mice blood at 1.565 and $3.125 \mu \mathrm{g} /$ wall, respectively. Administration of AH and AL extract led to 45 and $43 \%$ growth inhibition of EAC cells, respectively at $100 \mu \mathrm{g} / \mathrm{ml}$ with marked features of apoptosis including cell shrinkage, condensation of cytoplasm and aggregation of apoptotic bodies etc. Up-regulation of p53, Bax and caspase-3 and down-regulation of $\mathrm{Bcl}-2$ mRNA in Amaranthus treated mice indicated mitochondria mediated apoptosis of EAC cells in comparison with control. None of the bacterial species showed susceptibility to the extract of both the Amaranthus species.

Conclusion: Our current findings suggest that both of the Amaranthus species have strong antioxidant, lectin and anti-proliferative activity on EAC cells. The current anticancer potential was observed due mainly to the mitochondria mediated apoptosis of EAC cells.

Keywords: Amaranthus, Anticancer, Antimicrobial, Antioxidant, Apoptosis, EAC cells, Lectin and mice

* Correspondence: ferdousi_gen@ru.ac.bd

Protein Science Lab, Department of Genetic Engineering and Biotechnology,

University of Rajshahi, Rajshahi 6205, Bangladesh 


\section{Background}

Cancer is the prevalent worldwide fatal disease with high rate of mortality and morbidity. In 2012, an estimated 14.1 million new cases of cancer occurred and 8.2 million deaths worldwide [1]. The poor clinical outcomes against the cancer types are mainly attributed to the diversity in characteristics of specific cancer type and resistance to programmed cell death due to loss of the cellular ability to regulate the cell cycle negatively which allows the cells to proliferate abnormally and developing cancer [2]. Elevated level of reactive oxygen species (ROS), produced from both extracellular (irradiation) and intracellular (electron transport chain in mitochondria) sources reacts with DNA and cellular proteins, resulting base alteration, unstable genomes and genetic changes [3]. These types of molecular modifications lead to alter the normal apoptotic signaling machinery followed by uncontrolled cell proliferation and tumor formation [4]. Antioxidants are the biochemical constituents, produced in the body in insufficient amount, requiring external supply mainly from diet and having capacity to eliminate free radicals by neutralizing, quenching, reducing or through decomposing [5]. A plethora of studies suggest that there is strong correlation between the imbalance of antioxidant level and the development of several chronic diseases including cancer [6], neurologic disorder [7], cardiovascular disease [8] and age related disease [9].

Natural products are considered traditionally as the rich source of phytochemicals with various bio-structures and potent bioactivities against a number of diseases including cancer and infectious diseases. More than $80 \%$ of the total world's population relies on herbal medicine to meet their primary health care needs [10]. Current pharmaceutical industries are depending to a larger extant on natural products as a source of potential drug candidates as statistics show that over $60 \%$ of the current anticancer drugs are related with herbal product as their origin [11]. A range of studies have confirmed that plant derived materials possess potential bioactive compounds and exhibiting considerable antimicrobial [12], anticancer [13] and antioxidant [14] activity. Generally, phytochemicals exert their anti-proliferative role by modulating the apoptotic signaling pathways in cancer cells which is considered as the key event in the antitumor activity [15]. Though the chemotherapeutic drugs are the good option to remedy from cancer, but they are not devoid of some drawbacks such as severe side effects and drug resistance etc. Therefore, exploring novel plant derived bioactive agents having anticancer and antimicrobial potential would contribute to manage the drug resistance and toxicity.

Amaranthus belonging to the family of Amaranthaceae, having approximately 60 species, distributed throughout the tropical and subtropical countries including Bangladesh.
Different edible species of Amaranthus are being consumed widely as leafy vegetable across the world due mainly to its lower price and rich source of protein, carotenoids, vitamin $\mathrm{C}$, dietary fiber [16] and minerals such as calcium, iron, zinc and magnesium [17]. Several species of Amaranthus have been reported to contain various bioactive phytochemicals such as carotenoids, ascorbic acid, flavonoids and phenolic acids etc [18]. Amaranthus has well been documented to possess important pharmacological properties including anticancer [19, 20], anti-inflammatory [21] and antioxidant activity [18]. Among the Amaranthus species, AL (locally known Sobuj data) and AH (locally known Lal data) are prevalent in South East Asian territory and are being consumed by all classes of people especially lower income group. Both of the species are $100-300 \mathrm{~cm}$ in height and grow annually as an erect, monoecious herb with several branches $(30-60 \mathrm{~cm})$ containing flower as terminal whorls.

In spite of having potent anticancer role of different Amaranthus species $[19,20]$ as well as the popular use of $\mathrm{AL}$ and $\mathrm{AH}$ in Bangladesh, there are no sufficient reports regarding the anticancer and lectin activity of these two Amaranthus vegetable. However, lower income people in less developed countries comparatively evaded from this fetal disease especially from prostate and breast cancer [22] but they live on nothing but else rice and weedy vegetables including Amaranthus. Therefore, we were inspired from this finding and designed this study to evaluate antioxidant, lectin, antimicrobial as well as anticancer activity of these two Amaranthus species using the rodent animal (mouse) as diseases model containing EAC cells. Laboratory mouse is widely used as model organism, sharing $99 \%$ of their genes with human being along with very similar biochemical organization and serve as a safe and reliable platform to manipulate a complex disease process in a manner impossible to perform in patients [23, 24]. Laboratory mouse is being used for long time in different in vivo experiment to screen anticancer agent from plant sources $[25,26]$. Therefore, this study was carried out to evaluate the medicinal property of $\mathrm{AH}$ and $\mathrm{AL}$ in terms of antioxidant, anticancer as well as antimicrobial activity in the literature.

\section{Methods}

\section{Chemicals and reagents}

DPPH and Trypan blue dye, DAPI, Methanol (Sigma, USA); BHT and DMSO (Merck, Germany); M-MLV reverse transcriptase, $1^{\text {st }}$ strand buffer, dNTPs, and primer of oligo (dT), p53, Bax, caspase-3, Bcl-2 and $\beta$-actin (Tiangen Biotech, Beijing, China).

\section{Plant materials}

Fresh, young AL as well as mature $\mathrm{AH}$ plant with ripen seed were collected from the field of the surrounding 
area of Rajshahi, Bangladesh in January 2014. The identities of both the plant were authenticated by the taxonomist at the Botany Department of the University of Rajshahi, Bangladesh. A voucher specimen (Accession number: 1447) was deposited at the national herbarium Dhaka, Bangladesh.

\section{Determination of antioxidant activity Preparation of plant extract}

Both of the sample were sterilized properly using standard technique and shade dried at room temperature for 15 days and then grinded into fine powder. The resultant powder was added with $100 \%$ methanol and kept in a shaking incubator $(160 \mathrm{rpm})$ for $24 \mathrm{~h}$ at $37{ }^{\circ} \mathrm{C}$ followed by centrifugation at $8000 \mathrm{rpm}$ for $15 \mathrm{~min}$. The resultant pellets were remixed with the same percentage of methanol and kept at shaking incubator for $12 \mathrm{~h}$. The collected supernatants were filtered through filter paper and then allowing the filtrate to evaporate using a rotary evaporator for several times. The concentrated methanol extracts of $\mathrm{AL}$ and $\mathrm{AH}$ was stored at $-20{ }^{\circ} \mathrm{C}$ for $\mathrm{DPPH}$ radical scavenging assay.

\section{DPPH radical scavenging assay}

Antioxidant activity of both the plant extract was evaluated using DPPH radical scavenging assay [27]. An estimated $2.4 \mathrm{mg}$ of DPPH was dissolved in $100 \mathrm{ml}$ methanol and diluted with methanol to obtain an absorbance of $0.98( \pm 0.03)$ at $517 \mathrm{~nm}$ using the spectrophotometer (Thermo scientific, China). An aliquot of $100 \mu \mathrm{l}$ extract of both sample at the concentration of 25, 50 and $100 \mu \mathrm{g} / \mathrm{ml}$ were added in $3 \mathrm{ml} \mathrm{DPPH}$ solution, separately. Butylated hydroxytoluene (BHT) was used as standard. The mixtures were incubated in dark at room temperature for $20 \mathrm{~min}$ and the absorbance was recorded at $517 \mathrm{~nm}$. DPPH radical scavenging activity was calculated using the following formula:

$$
\text { Scavenging effect }(\%)=[(\text { Control absorbance })
$$$$
\text { - (sample absorbance }) /(\text { control absorbance })] \times 100
$$

\section{Determination of lectin activity}

The lectin activity of crud Amaranthus extracts was determined by hemmaglutination assay [28]. Briefly, the stem of AL ( $5 \mathrm{~g})$ and seed of $\mathrm{AH}(5 \mathrm{~g})$ were grinded with $1 \%$ sodium chloride saline $(3 \mathrm{ml} / \mathrm{g})$ using mortar and spatula and then centrifuged at $12000 \mathrm{rpm}$ for $5 \mathrm{~min}$ for 2 times. In a 96-well microtiter $U$ plate, $50 \mu$ l test sample was placed in the first well and then serially diluted into the successive wells with phosphate buffered saline (PBS), pH 7.4. An aliquot of $50 \mu \mathrm{l}$ of $2 \%$ mouse blood suspension was added in each wall. PBS alone was added as control. The titer plate was then kept at $37^{\circ} \mathrm{C}$ for $30 \mathrm{~min}$ and observed the agglutination of blood. Hemagglutination activity was assessed as agglutination of blood at lowest concentration of extract.

\section{Determination of anticancer activity Preparation of plant extract}

The water extract was used to evaluate the anticancer potential of Amaranthus species. In brief, the shade dried stem of AL and seed of AH were blended by a blander to get fine powder. Then 25, 50 and $100 \mu \mathrm{g}$ of resultant powder were mixed with $1 \mathrm{ml}$ deionized double distilled water $\left(\mathrm{dH}_{2} \mathrm{O}\right)$ and centrifuged at $12000 \mathrm{rpm}$ for $5 \mathrm{~min}$.

\section{Experimental animal, ethics statement and cancer cell inoculation and treatment}

A total of forty two mature female Swiss albino mice (25-30 g) were purchased from the Department of Pharmacy of Jahangernagar University, Dhaka, Bangladesh. The animals were kept in the animal house of the Department of Biochemistry and Molecular Biology, University of Rajshahi, Bangladesh. The methodology used in the current research work along with handling of experimental animal was approved by the Institutional Animal, Medical Ethics, Biosafety and Biosecurity Committee (IAMEBBC) for Experimentations on Animal, Human, Microbes and Living Natural Sources (license no: 225/320-IAMEBBC/IBSc), Institute of Biological Sciences, University of Rajshahi, Bangladesh.

EAC cells used in this study were kindly provided by Protein and Enzyme Laboratory, Department of Biochemistry and Molecular Biology, University of Rajshahi, Bangladesh. Mice were injected with EAC cells by successive transplantation of $6 \times 10^{6}$ cells/mouse in peritoneal cavity by needle aspiration with a volume of $0.2 \mathrm{ml}$ in PBS.

Mice injected with EAC cells on day zero were divided into two major groups namely treated and control group. Treated group was then divided into three subgroups (each group contain six animals) for each Amaranthus species as: group 1, group 2 and group 3, received 25, 50 and $100 \mu \mathrm{g} / \mathrm{ml} /$ day/mouse of test extracts, respectively after $24 \mathrm{~h}$ of EAC cells injection. Animals of the control group were received only $2 \%$ DMSO solution at $5 \mathrm{ml} / \mathrm{kg} / \mathrm{mouse} /$ day.

\section{Determination of cell growth inhibition}

The measurement of in vivo cancer growth inhibition was conducted by the method previously described by Sur et al. [29]. At the end of six days treatment, the animals were anesthetized using diethyl-ether and then intraperitoneal EAC cells were diluted with normal saline (0.98 \%) followed by harvesting with needle. Viable EAC cells were counted on hemocytometer using trypan blue 
dye with light microscope (optika, Italy). The cell growth inhibition was calculated using the following formula:

$$
\% \text { Cell growth inhibition }=(1-\mathrm{Tw} / \mathrm{Cw}) \times 100
$$

Where,

$\mathrm{Tw}=$ Mean number of EAC cells in the treated mice

$\mathrm{Cw}=$ mean number of EAC cells in the control mice.

\section{Apoptosis assessment by DAPI staining}

Collected EAC cells $(1 \mathrm{ml})$ from each group of mice were centrifuged at $1200 \mathrm{rpm}$ for $2 \mathrm{~min}$. The plate was then washed with PBS for each time after centrifugation at $1200 \mathrm{rpm}$ for $2 \mathrm{~min}$ for three times. The resultant cells were then incubated with $5 \mu$ l DAPI staining solution in dark for $10 \mathrm{~min}$ with subsequent adding of PBS to the DAPI containing pellet and then centrifuged at $1200 \mathrm{rpm}$ for $2 \mathrm{~min}$. Finally, $200 \mu \mathrm{L}$ PBS was added to the pellet and $10 \mu \mathrm{l}$ of the supernatant was taken on a microscopic slide and observed the morphological changes of cancer cells under the fluorescence microscope (XDS-2FL, Optika, Italy).

\section{RNA isolation, CDNA synthesis and PCR amplification of p53, Bax, Bcl-2 and caspase-3}

Total RNA was isolated from the EAC cells of both control and treated $(100 \mu \mathrm{g} / \mathrm{ml})$ mice using TIAGEN reagent kit according to the manufacturer's protocol. The quality of RNA was checked by $1 \%$ agarose gel electrophoresis, stained with $10 \mu \mathrm{g} / \mathrm{ml}$ ethidium bromide and visualized using gel documentation system (Alphaimager mini, Taiwan). The concentration and purity of isolated RNA was assessed by spectrometry at 260 and $280 \mathrm{~nm}$. Properly isolated RNA was converted to cDNA using reverse transcription master mix $(20 \mu \mathrm{l})$, containing $2 \mu \mathrm{l}$ oligo (dT), $1 \mu \mathrm{l}$ M-MLV reverse transcriptase, $2 \mu \mathrm{l}$ dNTPs, $4 \mu \mathrm{l} 5 \times 1^{\text {st }}$ strand buffer and $3 \mu$ total RNA sample and $8 \mu \mathrm{dH}_{2} \mathrm{O}$. The primer sequences used in the study are shown in Table 1. The thermal cycler (Gene Atlas 482, Japan) program for amplification reactions was set at $95{ }^{\circ} \mathrm{C}$ for $3 \mathrm{~min}, 95{ }^{\circ} \mathrm{C}$ for $1 \mathrm{~min}$ and $1 \mathrm{~min}$ for $52{ }^{\circ} \mathrm{C}$ (35 cycles) followed by $72{ }^{\circ} \mathrm{C}$ for $1 \mathrm{~min}$, and $72{ }^{\circ} \mathrm{C}$ for $10 \mathrm{~min}$ and eventually hold at $20{ }^{\circ} \mathrm{C}$. Relative expression of p53, Bax, Bcl-2 and caspase- 3 mRNA was measured by comparing with the expression of $\beta$-actin mRNA.

\section{Determination of Antibacterial activity}

\section{Extraction of total protein content for antibacterial assay}

Freshly collected stem of AL and seed $\mathrm{AH}$ were blended by mortar and spatula with Tris- $\mathrm{HCl}$ buffer. Then the resulted material was homogenized with Tris- $\mathrm{HCl}$ buffer $(1 \mathrm{ml} / 10 \mathrm{mg}$ plant materials) as well as $\beta$-mercapto ethanol $(1 \mu \mathrm{l})$ then vortexes for proper
Table 1 The primers used for PCR amplification

\begin{tabular}{ll}
\hline Gene & Primer sequence \\
\hline$\beta$-actin & Forward : 5'-GAGACCTTCAACACCCCAGC-3' \\
& Reverse : 5'-ATGTCACGCACGATTCCC-3' \\
p53 & Forward : 5'-CACAAAAACAGGTTAAACCCAG-3' \\
& Reverse : 5'-AGCACATAGGAGGCAGAGAC-3' \\
Caspase-3 & Forward : 5' - GCAGCAAACCTCAGGGAAAC-3' \\
& Reverse : 5'- GGTTCCCTGAGGTTTGCTG-3' \\
Bax & Forward : 5'-CCTGCTTCTTTCTTCATCGG-3' \\
& Reverse : 5'-AGGTGCCTGGACTCTTGGGT -3' \\
BCl-2 & Forward : 5'- GGCTGGGATGCTTTGTG-3' \\
& Reverse : 5'- GAGCAGTGCCTTCAGAGACAGC-3'
\end{tabular}

mixing. The homogenized mixture was then centrifuged at 10,000 rpm for $20 \mathrm{~min}$ and the supernatant was stored at $4{ }^{\circ} \mathrm{C}$.

\section{Disc diffusion assays}

Disc diffusion assay was carried out to measure the bacterial susceptibility to Amaranthus extract. The bacterial cultures used in the study were two Gram positive bacteria including Staphylococcus aureus (ATCC 29213) and Bacillus subtilis (ATCC 441) and three Gram negative bacteria including Escherichia coli (ATCC 25922), Pseudomonas aeruginosa (ATCC 27853) and Salmonella typhi. All the test microorganisms were kindly provided by Microbiology Laboratory, Department of Genetic Engineering and Biotechnology, University of Rajshahi, Bangladesh. Sterile paper discs (6 mm, Whatman, Maidstone, UK) were impregnated with both the plant extract $(50 \mu \mathrm{g} / \mathrm{disc})$. The test organisms $(100 \mu \mathrm{l})$ were inoculated on the surface of solid agar medium and incubated one hour before placing the paper discs. Then the agar plates were incubated at $37^{\circ} \mathrm{C}$ for $24 \mathrm{~h}$. Kanamycin $(15 \mu \mathrm{g} / \mathrm{disc})$ was used as positive control.

\section{Statistical analysis}

Statistical analyses for the assessment of antioxidant and growth inhibitory activity of Amaranthus extract in comparison with control was performed using one way ANOVA and student's $t$-test method. Data are expressed as mean $\pm \mathrm{SD}(n=3)$ for antioxidant study. Data are expressed as mean $\pm \mathrm{SD}(n=6)$ for anticancer study. The significance was set at $P<0.05$ and $P<0.01$.

\section{Results}

Antioxidant activity by DPPH radical scavenging assay DPPH radical scavenging activity of the extract of two Amaranthus species along with BHT standard is shown in Fig. 1. The methanol extracts of AL and $\mathrm{AH}$ exhibited dose dependent scavenging activity against DPPH free radicals. The seed extract of $\mathrm{AH}$ demonstrated higher free radical scavenging rate, exhibiting $\mathrm{IC}_{50}$ value of $28 \pm$ 


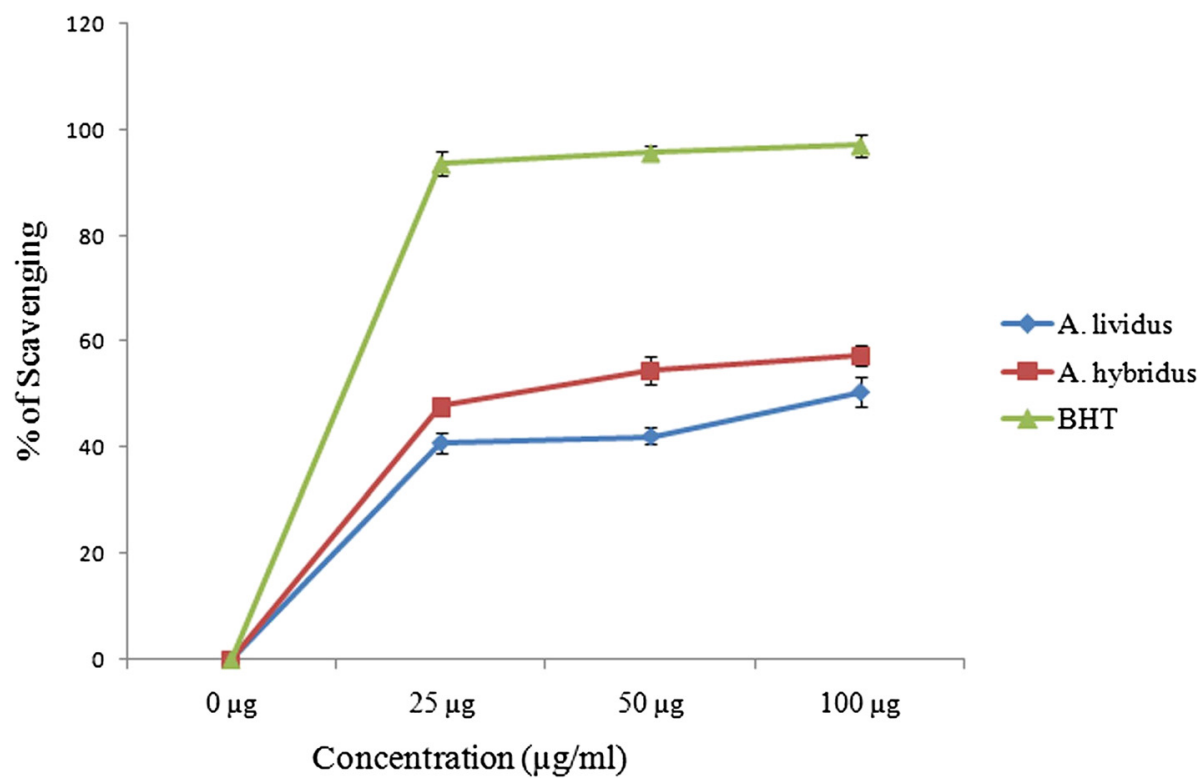

Fig. 1 DPPH radical scavenging activity of methanol extracts were isolated from the stem of AL and seed of AH. BHT was used as positive control. Each value represents a mean \pm SD $(n=3)$

$1.8 \mu \mathrm{g} / \mathrm{ml}$ (Table 2) over than the stem extract of AL (with $\mathrm{IC}_{50}$ value of $\left.93 \pm 2.44 \mu \mathrm{g} / \mathrm{ml}\right)$. However, the scavenging activity of both plant extract was less significant $(P<0.01)$ in comparison with BHT standard $\left(\mathrm{IC}_{50} 12 \pm 0.5 \mu \mathrm{g} / \mathrm{ml}\right)$.

\section{Assessment of lectin activity}

The hemagglutination activity of stem extract of AL and seed extract of AH is shown in Fig. 2. Both of the Amaranthus species demonstrated concentration dependant hemagglutination activity on mice blood. According to the data, the seed extract of AH shows hemagglutination activity at $1.565 \mu \mathrm{g} /$ wall, while the stem extract of AL required comparatively higher concentration $(3.125 \mu \mathrm{g} /$ wall $)$ to agglutinate the blood. However, negative control did not show hemagglutination activity at any concentration.

\section{Anticancer activity \\ Growth inhibitory activity of Amaranthus extract on EAC cells}

The anti-proliferative activity of two Amaranthus species is shown in Fig. 3 and Table 3. The percentage of EAC

Table 2 Half maximal inhibitory concentration $\left(\mathrm{IC}_{50}\right)$ of the $\mathrm{AL}$ and $\mathrm{AH}$ along with $\mathrm{BHT}$ standard

\begin{tabular}{lc}
\hline Samples & $\mid C_{50}$ values $(\mu \mathrm{g} / \mathrm{ml})$ \\
\hline A. lividus & $93 \pm 2.44$ \\
A. hybridus & $28 \pm 1.8$ \\
BHT & $12 \pm 0.5^{* *}$ \\
\hline
\end{tabular}

Each value is represented as mean $\pm \mathrm{SD}(n=3)$, significance was set at $P<0.01$ $(* *)$ with respect to $\mathrm{BHT}$ standard cells growth inhibition as a consequence of six days administration of Amaranthus extract is shown in Fig. 3b. Hemocytometer counting of EAC cells using trypan blue dye was shown to decrease the viability of EAC cells considerably in all treated groups in comparison with control. According to the data presented in Fig. 3b, seed extract of AH has relatively higher growth inhibitory activity and exhibiting 14, 26 and $45 \%$ growth inhibition at 25,50 and $100 \mu \mathrm{g} / \mathrm{ml}$, respectively over than stem extract of AL (12, 21 and $43 \%$, respectively) at the same concentration (Fig. 3b).

\section{Detection of apoptotic EAC cell by DAPI staining}

To observe the morphological changes of apoptotic EAC cells after the ending of six days treatment, DAPI staining was performed. Figure 4a reveals the marked feature of apoptosis in all the treated groups when compared with round shaped and less brightly stained control cells. Whereas the apoptotic cells or ongoing apoptotic cells exhibited bright blue color with condense chromatin. Reversely to the normal cells, the apoptotic cells exhibited characteristic apoptotic changes such as membrane blebbing, cell shrinkage, chromatin condensation, nuclear fragmentation and aggregation of apoptotic bodies etc (Fig. 4a). The average number of apoptotic cells/ slide is shown in Fig. 4b. Animals treated with both the Amaranthus extract at 50 and $100 \mu \mathrm{g} / \mathrm{ml}$ show significantly (at $P<0.05$ and $P<0.01$, respectively) elevated number of apoptotic cells in comparison with control mice. 


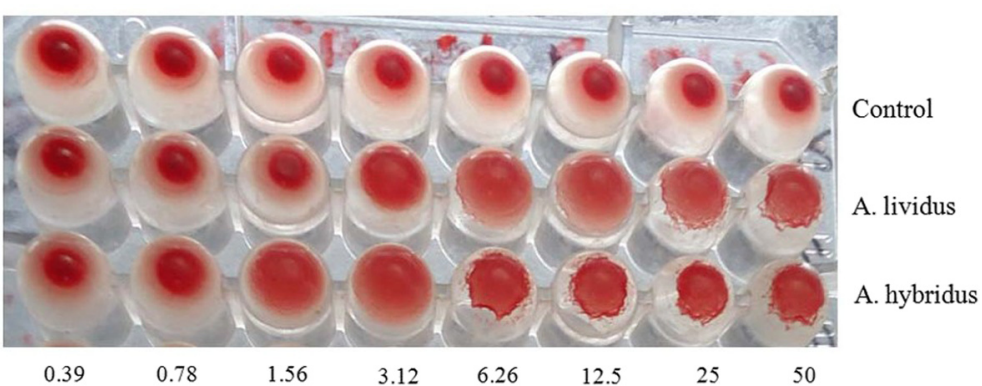

Fig. 2 Hemagglutination activity of crud extract of the stem of AL and seed of AH. Stem of AL shows hemagg lutination activity on mice blood at $3.125 \mu \mathrm{g} /$ wall, but in case of AH this activity was at $1.565 \mu \mathrm{g} /$ wall. The control titer-plate did not show hemagglutination at any concentration of PBS

\section{The contribution of $\mathrm{p} 53$, caspase-3, Bax and Bcl-2 in apoptosis}

To observe the expression pattern of several vital apoptotic markers such as p53, Bax, Bcl-2 and caspase-3, gene amplification study was conducted. The result from gene amplification study demonstrated that the animals treated with the extracts at $100 \mu \mathrm{g} / \mathrm{ml}$ showed up-regulation of p53, Bax and caspase- 3 mRNA when compared with their respective controls (Fig. 5b). Considerably lower expression of Bcl-2 mRNA in $100 \mu \mathrm{g} /$ $\mathrm{ml}$ treated mice was also observed, which indicates mitochondria mediated apoptosis of EAC cells.

\section{Assessment of antimicrobial activity}

The bacterial susceptibility to the crud protein of AL and $\mathrm{AH}$ is shown in Fig. 6. Both of the plant extract exhibited negligible inhibition of bacterial growth in comparison with the positive control (both at $P<0.05$ and $P<0.01$ ). Among the bacterial species $E$. coli shows comparatively higher sensitivity to the Amaranthus extract $(8.6 \pm 0.79 \mathrm{~mm}$ for AL extract and $9.4 \pm 0.61 \mathrm{~mm}$ for AH extract).

\section{Discussion}

Nowadays, scientific communities and pharmaceutical companies are aim to find out bioactive phytochemicals

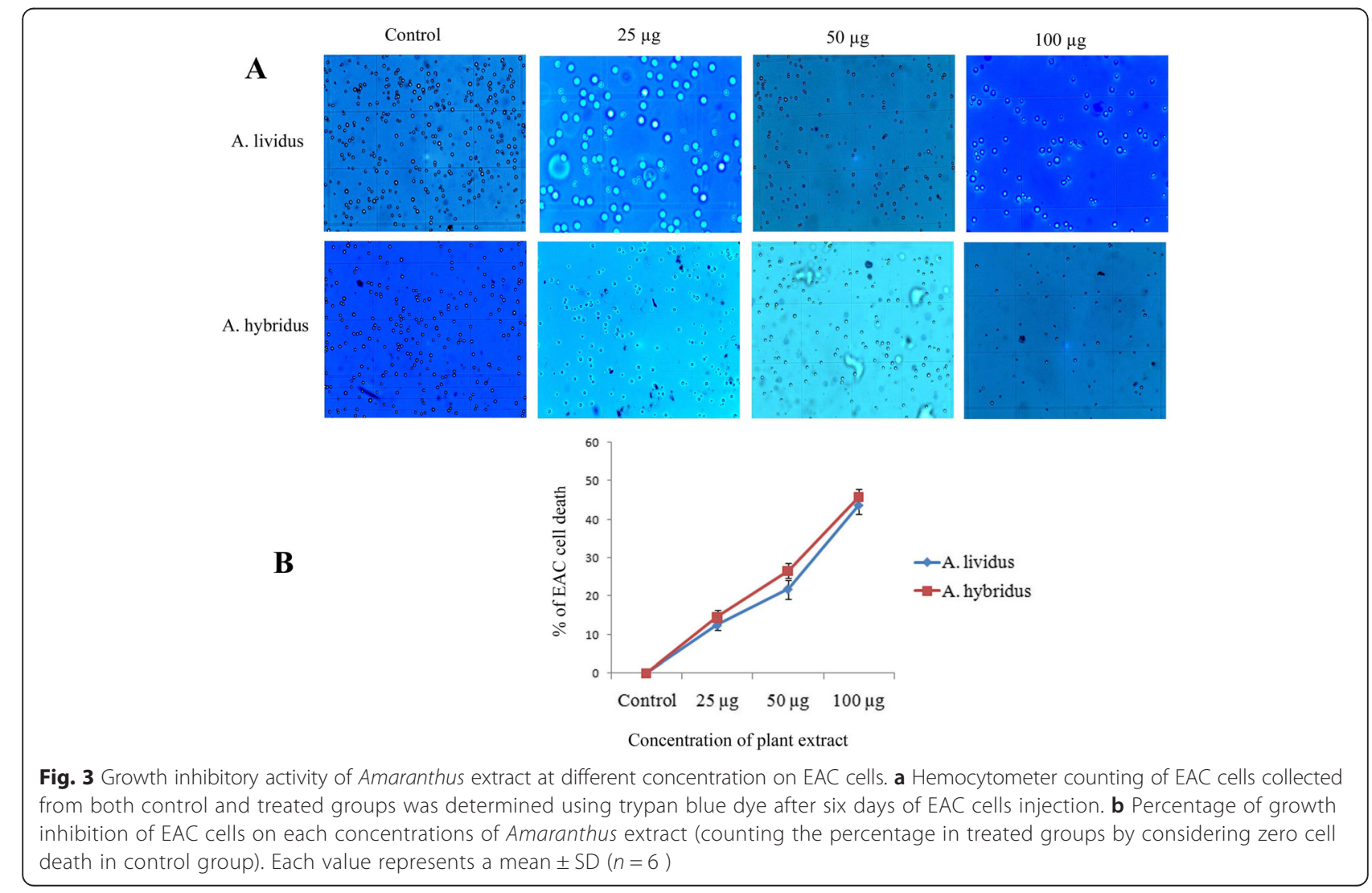


Table 3 Growth inhibitory activity of Amaranthus extract on EAC cells by hemocytometer counting using trypan blue dye

\begin{tabular}{lllll}
\hline Plants & \multicolumn{4}{l}{ Average count of EAC cells per cell of hemocytometer (out of 16 cells) } \\
\cline { 2 - 5 } & Control & $25 \mu \mathrm{g}$ & $50 \mu \mathrm{g}$ & $100 \mu \mathrm{g}$ \\
\hline A. lividus & $32 \pm 0.52$ & $28 \pm 0.56$ & $25 \pm 0.38^{*}$ & $18 \pm 0.33^{* *}$ \\
A. hybridus & $32 \pm 0.52$ & $27.37 \pm 0.5$ & $23.37 \pm 0.58^{*}$ & $17.25 \pm 0.41^{* *}$ \\
\hline
\end{tabular}

Each value is represented as mean $\pm \mathrm{SD}(n=6)$, significance was set at $P<0.05\left(^{*}\right)$ and $P<0.01\left(^{* *}\right)$ with respect to control

exerting health-promoting benefits in a non toxic way. Combination of chemotherapeutic agents with naturally occurring tumor active compounds such as polyphenols would be better able to overcome mechanisms of drug resistance. Excessive ROS levels in normal cells has been reported to be involved in various aspects of carcinogenesis by altering cellular signaling and gene expression pattern [4, 30]. Plant derived dietary compounds play anticancer role either by increasing ROS level in cancer cells, resulting induction of programmed cell death or counter-regulating elevated ROS level in normal cells by antioxidant mechanism [31]. The antioxidant molecules can balance the ROS level either by neutralizing and producing less active, longer-lived and less dangerous new free radicals or destroy them by reacting with the reactive radicals directly.

In the present study, we have investigated antioxidant, lectin, antimicrobial and anticancer activity of stem and seed extract of two vegetable species of Amaranthus using different staining and gene expression technique. Stem extract of AL and seed extract of AH at different concentrations exhibited strong scavenging activity against DPPH stable radicals (Fig. 1). A number of Amaranthus species have been proven previously to possess considerable antioxidant capacity. However, our current findings show that methanol extract of AL and $\mathrm{AH}$ exhibited comparatively higher antioxidant potential than those of other species of Amaranthus even the other extracts of these species [32, 33].

The strong anticancer activity in this study would be the result of lectin activity present in the Amaranthus extract. Lectins are a class of glycoprotein present mainly in plant especially in seed in abundant quantity and having carbohydrate binding capacity. Lectin activity in plant sample is usually determined by hemagglutination assay. The elevated hemagglutination activity of seed extract over stem

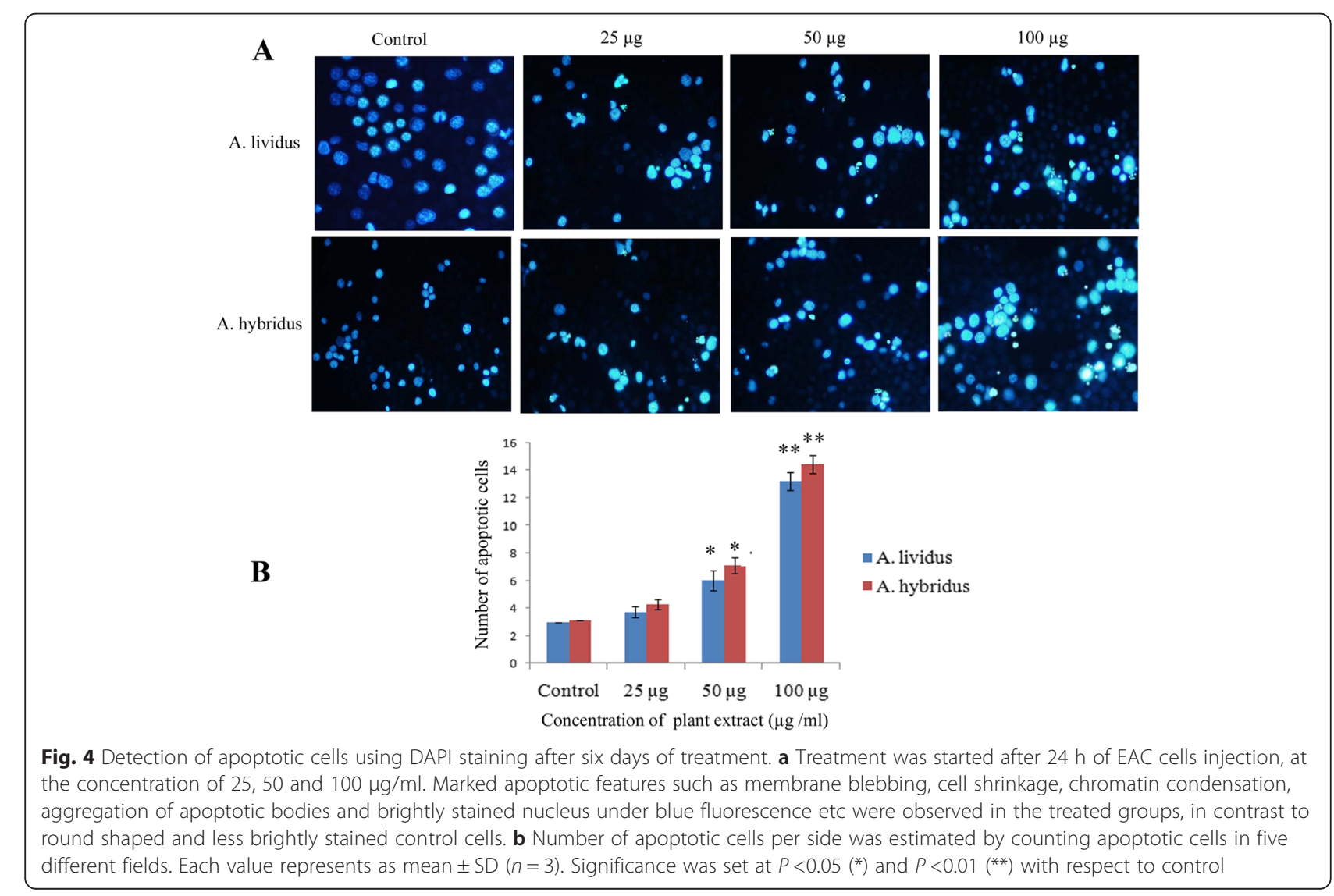




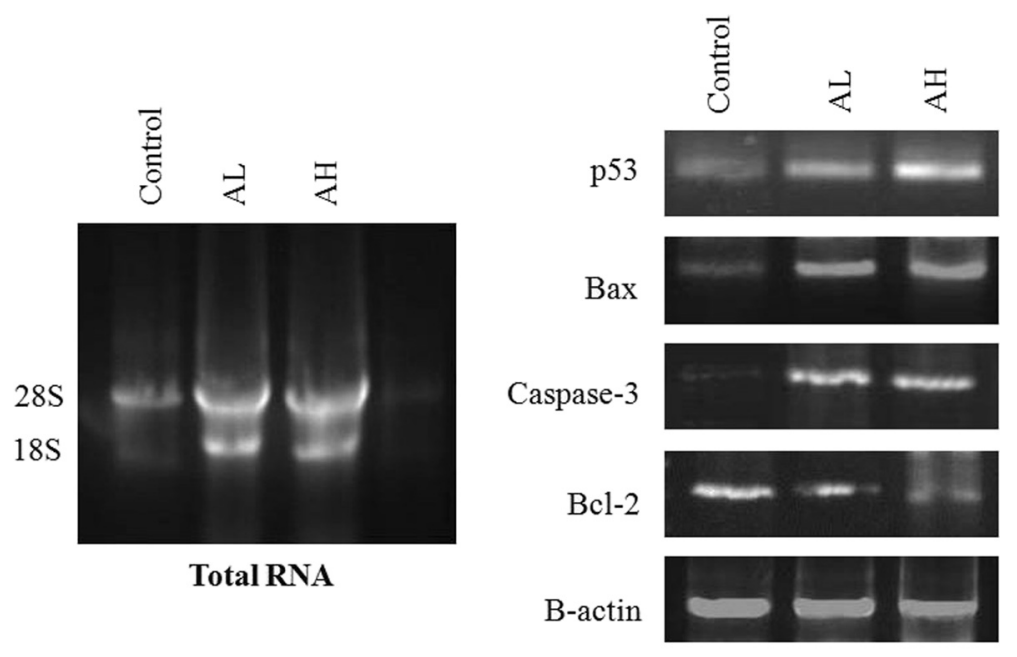

A

B

Fig. 5 Apoptotic changes of EAC cells induced by Amaranthus extract were found to mediated by mitochondrial pathway: a Isolated total RNA exhibited two separate bands as $28 \mathrm{~S}$ and $18 \mathrm{~S}$. $\mathbf{b}$ The animals treated with Amaranthus extract at $100 \mu \mathrm{g} / \mathrm{ml}$ for six days exhibited relatively up-regulation of p53, Bax and caspase- 3 and showing bright and bolder band in comparison with control. While the expression of Bcl-2 mRNA was decreased considerably when compared with the control. Beta-actin was used as standard

extract is also supported by a number of studies which show that higher lectin content in seed sample over than the other parts of the plant [34]. Higher lectin activity of seed sample also supports the comparative higher anti-proliferative outcome of seed extract over the stem extract in the current study (Fig. 3). Since, lectin has been reported to possess remarkable anti-antitumor activity, exerting apoptotic role by preferential binding to cancer cell membranes with subsequent cytotoxicity [35]. Lectin also exhibits growth inhibitory activity by altering the cell cycle and inducing non-apoptotic G1phase accumulation mechanisms, G2/M phase cell cycle arrest and apoptosis [36]. Therefore, plant lectin can be considered as a potential agent for combinational therapy against a range of cancer cell lines. Nevertheless, the crude protein of two vegetable species

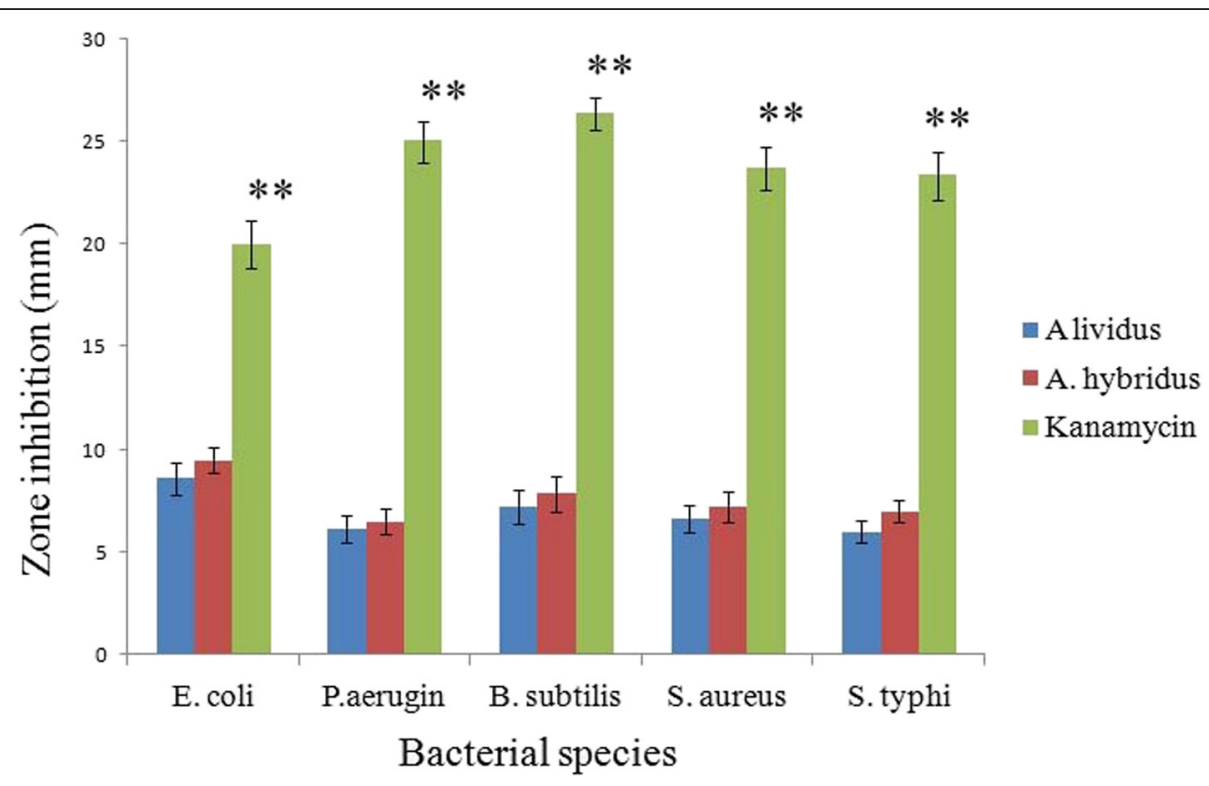

Fig. 6 Bacterial susceptibility to the crud protein of two Amaranthus species was conducted using disc diffusion assay. Antimicrobial activity was determined by measuring the zone of inhibition in millimeter $(\mathrm{mm})$. Kanamycin $(15 \mu \mathrm{g} / \mathrm{disc})$ was used as positive control. Each value represents a mean $\pm \mathrm{SD}(n=3)$. Significance was set at $P<0.05\left(^{*}\right)$ and $\left.P<0.01{ }^{* *}\right)$ with respect to control 
of Amaranthus did not show considerable antimicrobial activity against tested pathogenic bacteria (Fig. 6). Such insignificant antimicrobial activity of $\mathrm{AH}$ and AL has also been documented previously in case of other Amaranthus species [37].

Apoptosis is an ideal way of cell death by which the body selectively eliminates unnecessary cells or unhealthy cells in a series of sequential events without affecting surrounding normal cell. Inhibition of apoptosis is the critical early event in tumor development, which allows the cell to proliferate abnormally and leading to the development of cancer [38]. Therefore, induction of apoptosis is considered as a central strategy and a useful indicator for almost every type's cancer treatment and prevention. Trypan blue dye and DAPI staining study exhibited the growth inhibitory activity of Amaranthus extracts on EAC cells by induction of apoptosis. The number of viable cells were found to be decreased by around $45 \%$ (Fig. 3) at $100 \mu \mathrm{g} / \mathrm{ml}$, indicating significant growth inhibitory activity of Amaranthus extracts on cancer cells (Fig. 3b). The dose dependant depletion of EAC cells is considered to be the result of induction of apoptosis pathway which modulates cells death [39]. DAPI staining clearly demonstrated the critical morphological features of apoptosis including membrane blebbing, cell shrinkage, chromosome condensation, nuclear fragmentation and aggregation of apoptotic bodies etc. Membrane blebbing and cell shrinkage are considered to be the key morphological alterations of early apoptotic cells. Whereas DNA fragmentation and aggregation of apoptotic bodies are the end products of apoptosis and would be the result of catalytic activities of executioner caspases (caspases-3 and caspases-7).

Apoptosis involves a series of sequential proteinprotein interactions which is basically regulated by the ratio of anti-apoptotic and pro-apoptotic proteins belonging to Bcl-2 family. Anti-apoptotic Bcl-2-like proteins (e.g. Bcl-2, Bcl-xL, Bcl-w, Mcl-1 and A1/Bfl-1) down-regulate apoptosis by protecting mitochondrial membrane potential, whereas pro-apoptotic Bax-like proteins (e.g. Bax, Bak and Bok/Mtd) up-regulate apoptosis by creating pore on the mitochondrial membrane. It has been well reported that plant derived phytochemicals induce oxidative DNA damage in cancer cells by producing elevated level of ROS [31] which in turn induces up-regulation of $\mathrm{p} 53$, the critical regulator of mitochondria mediated apoptosis, inducing apoptosis by up-regulating some critical apoptotic modulators such as puma, Noxa and Bax [40, 41]. Activated Bax then translocates to and inserts into the mitochondrial outer membrane [42] with subsequent releasing of cytochrome $c$ (Cyt $c$ ) in the cytosol. Mitochondrial Cyt $c$ in cytosol binds with its binding partner Apaf- 1 which in turn binds with procaspase-9 and forms a large wheel like multi-protein complex "apoptosome" [43]. The activated caspase- 9 then cleaves the proenzyme form of the effector caspases such as caspase-3, caspase- 6 and caspase-7 [44]. Caspase- 3 is the key effectors caspase in apoptosis which acts by restricted proteolysis of important cellular proteins mainly the structural proteins such as cytokeratins, PARP and nuclear protein NuMA, resulting cell death [45]. Therefore, we have evaluated the expression pattern of these apoptotic markers in Amaranthus treated animals and in the control counterparts in this study. The up-regulation of p53, Bax and caspase-3 mRNA as well as down-regulation of Bcl-2 mRNA in treated mice indicated the induction of mitochondria mediated apoptosis of EAC cells. The apparent apoptotic features in DAPI staining EAC cells of treated mice also support the alteration of genetic expression indicating apoptotic death of cancer cells. The outcomes of our current study are in accord with a number of observations which demonstrated that the bioactive phytochemicals generate elevated level ROS which in turn induces mitochondria mediated apoptosis by up-regulating the expression of p53 and pro-apoptotic proteins (Bax) and down-regulating the expression of anti-apoptotic proteins (Bcl-2) follwed by activating caspases-3 $[15,46]$. Therefore, it could be postulated that the phytochemicals (lectins, polyphenols, flavonoids) present in Amaranthus extract would produce elevated level of ROS which in turn induces over-expression of p53 and induction of mitochondria mediated apoptosis of EAC cells.

Here, the anticancer activity of the stem extract of AL and seed extract of AH on EAC cells could be attributed to the presence of a variety of bioactive phytochemicals. Till date we do not know what bioactive compound played the key anti-proliferative role on EAC cells. Another limitation of this study is that we did not carry out anti-proliferative study on in vitro cell line. Furthermore, detection of specific bioactive phyto-ingredients demonstrating anticancer effect will be of great therapeutic value. Nevertheless the current study provides the proof of strong evidence that Amaranthus possesses potent anticancer property with great health benefit to common people and can be considered as a potential target for future research.

\section{Conclusion}

In conclusion, our data suggest that the treatment of EAC cells with lectin rich Amaranthus extract inhibited the growth of cancer cells by induction of apoptosis. The gene expression pattern in Amaranthus treated mice clearly exhibited that the stem extract of $\mathrm{Al}$ and seed extract of $\mathrm{AH}$ induced mitochondria mediated apoptosis of EAC cells. However, the complete mechanisms underlying the therapeutic effects of the extract such as cytotoxicity need to be investigated as an approach for the 


\section{development of effective combinational therapy against a range of cancer cell line.}

\begin{abstract}
Abbreviations
$\%$, percentage; AH, Amaranthus hybridus; AL, Amaranthus lividus; ANOVA, one way analysis of variance; BHT, Butylated hydroxytoluene; DAPI, 4',6-diamidino-2phenylindole; DMSO, Dimethyl sulfoxide; EAC, Ehrlich's ascites carcinoma; mg, milligramme; $\mathrm{mL}$, milliliter; $\mathrm{nm}$, nanometer; PBS, phosphate buffered saline; ROS, Reactive oxygen species; rpm, rotation per minutes; Tris-HCl, Tris- hydrochloric acid; $\mu \mathrm{L}$, microliter
\end{abstract}

\section{Acknowledgement}

This work was funded internally by the Department of Genetic Engineering and Biotechnology, University of Rajshahi, Bangladesh. The authors are thankful to Dr. Rassel Kobir, Associate professor, Protein and Enzyme laboratory, Department of Biochenistry and Mlecular Biology, University of Rajshahi, Bangladesh and Dr. Md. Salah Uddin, Assitant professor, Microbiology laboratory, Dept of Genetic Engineering and Biotechnology, University of Rajshah for technical and Lab support.

\section{Funding}

This work was funded internally by the Department of Genetic Engineering and Biotechnology, University of Rajshahi, Bangladesh.

\section{Availability of data and materials}

The datasets supporting the conclusions of this article are included within the article.

\section{Authors' contributions}

MAM, AR and ZF conceived and designed the study. MAM, JHS and MK conducted the study under the supervision of ZF and AR. KMH collected and analyzed the data. RH and MK handled with rodent animal and collected the plant materials. MAM wrote the first drift of manuscript and AR and ZF revised the manuscript. All authors read and approved the final draft of manuscript.

\section{Competing interest}

The authors declare that they have no competing interests.

\section{Consent for publication}

Not applicable.

\section{Ethics approval and consent to participate}

The methodology used in the current research work along with handling of experimental animal and microorganism was approved by the Institutional Animal, Medical Ethics, Biosafety and Biosecurity Committee (IAMEBBC) for Experimentations on Animal, Human, Microbes and Living Natural Sources (license no: 225/320-IAMEBBC/IBSC), Institute of Biological Sciences, University of Rajshahi, Bangladesh.

\section{Received: 6 January 2016 Accepted: 18 May 2016}

\section{Published online: 31 May 2016}

\section{References}

1. Anon. Cancer fact and figure 2015. Atlanta: American cancer society; 2015.

2. Hanahan D, Weinberg RA. Hallmarks of cancer. Cell. 2000;100:57-70.

3. Halliwell B. Oxidative stress and cancer: have we moved forward? Biochem J. 2007:401:1-11

4. Fruehauf JP, Meyskens FL. Reactive oxygen species: A breath of life or death. Clin Cancer Res. 2007;13:789-94.

5. Lü JM, Lin PH, Yao Q, Chen C. Chemical and molecular mechanisms of antioxidants: experimental approaches and model systems. J Cell Mol Med. 2010;14:840-60.

6. Valko M, Rhodes CJ, Moncol J, Izakovic M, Mazur M. Free radicals, metals and antioxidants in oxidative stress-induced cancer. Chem Biol Interact. 2006;160:1-40

7. Halliwell B. Role of free radicals in neurodegenerative diseases: therapeutic implications for antioxidant treatment. Drugs Aging. 2001;18:685-716.

8. Manson JE, Gaziano JM, Jonas MA, Hennekens CH. Antioxidants and cardiovascular disease: a review. J Am Coll Nutr. 1993;12:426-32.

9. Sadowska-Bartosz I, Bartosz G. Effect of antioxidants supplementation on aging and longevity. Biomed Res Int. 2014;2014:404680.
10. Gao PF, Watanabe K. Introduction of the World Health Organization project of the International Classification of Traditional Medicine. Zhong Xi Yi Jie He Xue Bao. 2011;9:1161-4.

11. Cragg GM, Newman J. Plants as a source of anti-cancer and anti-HIV agents. Ann Appl Biol. 2003;143:127-33.

12. Al-Mamun MA, Akhter R, Rahman A, Ferdousi Z. Efficient in vitro micro propagation of Andrographis paniculata and evaluation of antibacterial activity from its crude protein extract. European J Med Plants. 2015;6:231-41.

13. Fadeyi SA, Fadeyi OO, Adejumo AA, Okoro C, Myles EL. In vitro anticancer screening of 24 locally used Nigerian medicinal plants. BMC Complement Altern Med. 2013;13:79.

14. Saeed N, Khan MR, Shabbir M. Antioxidant activity, total phenolic and total flavonoid contents of whole plant extracts Torilis leptophylla L. BMC Complement Altern Med. 2012;12:221.

15. Arul D, Subramanian P. Naringenin (Citrus Flavonone) Induces Growth Inhibition, Cell Cycle Arrest and Apoptosis in Human Hepatocellular Carcinoma Cells. Pathol Oncol Res. 2013;19:763-70.

16. Shukla S, Bhargava A, Chatterjee A, Srivastava J, Singh N, Singh SP. Mineral profile and variability in vegetable amaranth (Amaranthus tricolor). Plant Foods Hum Nutr. 2006;61:23-8.

17. Kadoshnikov SI, Kadoshnikova IG, Kulikov YA, Martirosyan DM. Researches of fractional composition of protein of amaranth. Curr Nutr Food Sci. 2008;4: 196-205.

18. Amin I, Norazaidah Y, Emmy Hainida Kl. Antioxidant activity and phenolic content of raw and blanched Amaranthus species. Food Chem. 2006;94:47-52.

19. Sani HA, Rahmat A, Ismail M, Rosli R, Endrini S. Potential anticancer effect of red spinach (Amaranthus gangeticus) extract. Asia Pac J Clin Nutr. 2004;13: $396-400$.

20. Baskar AA, Al Numair KS, Alsaif MA, Ignacimuthu S. In vitro antioxidant and antiproliferative potential of medicinal plants used in traditional Indian medicine to treat cancer. Redox Rep. 2012;17:145-56.

21. Tyszka-Czochara M, Pasko P, Zagrodzki P, Gajdzik E, Wietecha-Posluszny R, Gorinstein S. Selenium Supplementation of Amaranth Sprouts Influences Betacyanin Content and Improves Anti-Inflammatory Properties via NFkB in Murine RAW 264.7 Macrophages. Biol Trace Elem Res. 2016;169:320-30.

22. World Bank income groups and by sex. Burden: mortality, morbidity and risk factors Chapter 1. 2008. p. 1-31.

23. Frese KK, Tuveson DA. Maximizing mouse cancer models. Nat Rev Cancer. 2007;7:645-58.

24. Rosenthal N, Brown S. The mouse ascending: perspectives for humandisease models. Nat Cell Biol. 2007;9:993-9.

25. Islam S, Nasrin S, Khan MA, Hossain AS, Islam F, Alam AH, et al. Evaluation of antioxidant and anticancer properties of the seed extracts of Syzygium fruticosum Roxb. growing in Rajshahi, Bangladesh. BMC Complement Altern Med. 2013;13:142.

26. Ahmed HH, Hegazi MM, Abd-Alla HI, Eskander EF, Ellithey MS. Antitumour and antioxidant activity of some Red Sea seaweeds in Ehrlich ascites carcinoma in vivo. Z Naturforsch C. 2011;66:367-76.

27. Velázquez E, Tournier HA, Mordujovich de Buschiazzo P, Saavedra G, Schinella GR. Antioxidant activity of Paraguayan plant extracts. Fitoterapia. 2003;74:91-7.

28. Correia MT, Coelho LC. Purification of a glucose/mannose specific lectin, isoform 1, from seeds of Cratylia mollis Mart. (Camaratu bean). Appl Biochem Biotechnol. 1995;55:261-73.

29. Sur P, Ganguly DK. Tea Plant Root Extract (TRE) as an Antineoplastic Agent. Planta Med. 1994;60:106-9.

30. Murray Jl, Whitfield ML, Trinklein ND, Myers RM, Brown PO, Botstein D. Diverse and specific gene expression responses to stresses in cultured human cell. Mol Biol Cell. 2004;15:2361-74.

31. Quideau S, Deffieux D, Douat-Casassus C, Pouysegu L. Plant polyphenols: chemical properties, biological activities, and synthesis. Angewandte Chemie. 2011;50:586-621.

32. Ozsoy N, Yilmaz T, Kurt O, Can A, Yanardag R. In vitro antioxidant activity of Amaranthus lividus L. Food Chem. 2009;116:867-72.

33. Oboh G. Effect of blanching on the antioxidant properties of some tropical green leafy vegetables. Lebenson Wiss Technol. 2005;38:513-7.

34. Jeyaprakash AA, Jayashree G, Mahanta SK, Swaminathan CP, Sekar K, Surolia $A$, et al. Structural basis for the energetics of jacalin-sugar interactions: promiscuity versus specificity. J Mol Biol. 2005;347:181-8.

35. Kim M, Rao MV, Tweardy DJ, Prakash M, Galili U, Gorelik E. Lectin-induced apoptosis of tumour cells. Glycobiology. 1993;3:447-53. 
36. De Mejía EG, Prisecaru VI. Lectins as bioactive plant proteins: a potential in cancer treatment. Crit Rev Food Sci Nutr. 2005;45:425-45.

37. Kumar BSA, Lakshman K, Jayaveera KN, Shekar DS, Kumar AA, Manoj B. Antioxidant and antipyretic properties of methanolic extract of Amaranthus spinosus leaves. Asian Pac J Trop Med. 2010;3:702-6.

38. Brown JM, Attardi LD. The role of apoptosis in cancer development and treatment response. Nat Rev Cancer. 2005;5:231-7.

39. Fadeel B, Orrenius S. Apoptosis: a basic biological phenomenon with wideranging implications in human disease. J Intern Med. 2005;258:479-517.

40. Oda E, Ohki R, Murasawa H, Nemoto J, Shibue Tand Tanaka N, et al. Noxa, a $\mathrm{BH} 3-$ only member of the $\mathrm{BCl}-2$ family and candidate mediator of $\mathrm{p53}$ induced apoptosis. Science. 2000;288:1053-8.

41. Chipuk JE, Kuwana T, Bouchier-Hayes L, Droin NM, Newmeyer DD, Green DR, et al. Direct activation of Bax by p53 mediates mitochondrial membrane permeabilization and apoptosis. Science. 2004;303:1010-4.

42. Billen LP, Kokoski CL, Lovell JF, Leber B, Andrews DW. BCl-XL inhibits membrane permeabilization by competing with Bax. PLoS Biol. 2008;6:e147.

43. Hill MM, Adrain C, Duriez PJ, Creagh EM, Martin SJ. Analysis of the composition, assembly kinetics and activity of native Apaf-1 apoptosomes. Embo J. 2004:23:2134-45.

44. Slee EA, Harte MT, Kluck RM, Wolf BB, Casiano CA, Martin SJ, et al. Ordering the cytochrome $c$-initiated caspase cascade: Hierarchical activation of caspases-2, -3, -6, -7, -8, and -10 in a caspase-9-dependent manner. J Cell Biol. 1999;1999(144):281-92.

45. Slee EA, Adrain C, Martin SJ. Executioner caspase-3, -6, and -7 perform distinct, non-redundant roles during the demolition phase of apoptosis. J Biol Chem. 2001;276:7320-6.

46. Pal HC, Sharma S, Elmets CA, Athar M, Afaq F. Fisetin inhibits growth, induces G2/M arrest and apoptosis of human epidermoid carcinoma A431 cells: Role of mitochondrial membrane potential disruption and consequent caspases activation. Exp Dermatol. 2013;22:470-5.

\section{Submit your next manuscript to BioMed Central} and we will help you at every step:

- We accept pre-submission inquiries

- Our selector tool helps you to find the most relevant journal

- We provide round the clock customer support

- Convenient online submission

- Thorough peer review

- Inclusion in PubMed and all major indexing services

- Maximum visibility for your research

Submit your manuscript at www.biomedcentral.com/submit
Biomed Central 